\title{
Cuentos Bilingües Pasqueños Para Mejorar El Aprendizaje Del Idioma Inglés
}

Bilingual Pasqueños Stories to Improve English Language Learning

\section{Oscar Abel Figueroa Mejía}

Maestro en Didáctica en Idiomas Extranjeros, Universidad César Vallejo, Lima, Perú

oscarfigueroamejia2401@gmail.com ORCID:org/ 0000-0001-8630-9735

https://scholar.google.com/citations?view_op=new_profile\&hl=es

\section{Isabel María Astuvilca Quijada}

Maestra en Psicología Educativa, Universidad César Vallejo. Lima - Perú

belastuqui7@gmail.com ORCID: 0000-0001-7217-5924

https://scholar.google.com/citations?user=_SpWukUAAAAJ\&hl=es

\section{Ysela Janet Lazo Tafur}

Maestra en Gestión Pública , Universidad César Vallejo. Lima - Perú

(ORCID: 0000-0002-5563-1251)

yselalazo@gmail.com

https://scholar.google.es/citations?hl=es\&user=MWXASKAAAAAJ

\section{Gilbert Valerio, Montalvo Cobos}

Maestría en Problemas de Aprendizaje. Universidad Nacional de Educación

ORCID: 0000-0002-1866-6631.

gilbertmontalvo58@gmail.com.

https://scholar.google.es/scholar?hl=es\&as_sdt=0\%2C5\&q

Revista Iberoamericana de la Educación

Vol - Especial 12021

e-ISSN: 2737-632x 
Abstract: This project was conducted at the Benemérita Sociedad Filantrópica Educational Unit in the seventh grade of basic education, school year 2015 - 2016. The objective of the research was to examine the influence of critical reading on the quality of meaningful learning through a bibliographic study and statistical field analysis. The research used surveys that were applied to teachers, administrators and students of the school, the data analysis detailed the lack of interest shown by students towards reading, making the comprehension of reading complex. From the students' perspective, the readings done in class become theoretical and tedious, which leads them to be easily distracted in the teaching-learning process. This has created barriers at the moment of encouraging active interaction among class members. On the other hand, it was found that some teachers did not apply dynamic activities that relate educational content with different experiences, minimizing the development of meaningful learning in students. This series of aspects led to the elaboration of a proposal that allows teachers to apply innovative activities that can be adapted to the different educational content present in the area of Language and Literature.

Key words: Critical reading, learning, dynamics

Resumen: El presente proyecto se lo ha realizado en la Unidad Educativa Benemérita Sociedad Filantrópica en el séptimo grado de educación básica, periodo lectivo 2015 - 2016. El objetivo de la investigación fue examinar la influencia de la lectura crítica en la calidad del aprendizaje significativo mediante un estudio bibliográfico y análisis estadístico de campo. En la investigación se emplearon encuestas que se aplicaron a docentes, directivos y estudiantes del plantel, el análisis de los datos detalló la falta de interés que presentan los estudiantes hacia la lectura, tornando compleja la comprensión de la misma. Desde la perspectiva de los estudiantes, las lecturas realizadas 
en clase se tornan teóricas y tediosas, lo cual los direcciona a distraerse con facilidad dentro del proceso de enseñanza-aprendizaje. Esto ha creado barreras al momento de fomentar la interacción activa entre los miembros de la clase. Por otra parte, se constató que algunos docentes no aplicaban actividades dinámicas que relacionen los contenidos educativos con diversas experiencias vividas minimizando el desarrollo de aprendizajes significativos en los estudiantes. Esta serie de aspectos fundamentaron la elaboración de una propuesta que permita al docente aplicar actividades innovadoras que puedan adaptarse a los diferentes contenidos educativos presentes en el área de Lengua y Literatura.

Palabras clave: Lectura crítica, aprendizaje, dinámica

\section{INTRODUCTION}

Nowadays it is essential that students can count on a quality education that allows them to understand each of the contents developed in class in a comprehensive and meaningful way, minimizing the impact of the different aspects that affect the normal development of the student, when there are deficiencies in critical reading, the student is directed to minimize the essential analysis processes in the school stage, which directly influences their academic performance.

One of the aspects observed is framed in the traditional pedagogy applied by several teachers, which does not allow the development of an environment that favors the active participation of each of the students to integrate their knowledge in the resolution of situations and problems that are generated in daily life, taking away the necessary relevance of critical reading.

For the present research project, the following question was considered: how does critical reading influence the quality of meaningful learning in the 
writing of seventh grade students of general basic education in the area of Language and Literature.

The lack of strategies that promote a more critical reading in students is one of the problems that most affect the low school performance of students in the area of language and literature, because it fails to grasp the message of reading and therefore does not give the necessary importance at the time of using it in the resolution of situations that arise in the school environment.

When students do not focus their attention on the contents proposed by the teacher, it is much more difficult for them to understand what is proposed in class, minimizing the creation of significant learning that can be put into practice in daily life, directly affecting their process of adaptation to the group in which they develop.

It is necessary that the directors of the school constantly evaluate the teachers, certifying that each of the plans include activities directed to a specific year and area of basic general education, emphasizing that each child is a different world and therefore it is important that the classes become inclusive and inclusive, focusing the teacher's attention on the group in charge.

This research on critical reading allows us to learn more about the shortcomings of the students, with the goal of helping to develop techniques for rapid, comprehensive and critical reading, which are the cause that led us to study it.

Through the analysis of the students' environment, it can be seen that little support is provided at home, due to factors such as parents who work and leave their children alone all day, migrant parents with children in the care of grandparents or uncles, illiterate parents who immigrated from rural areas to the city, the socio-affective factor, parents with alcohol and drug problems, among others. 
One of the main objectives is to determine the influence of critical reading on the quality of meaningful learning, through a bibliographic and field study, and statistical analysis, in order to design a didactic guide focused on skills with performance criteria.

The main beneficiaries would be the students, teachers and legal representatives who will be able to satisfy their needs and interests in terms of improving the quality of correct reading, with the application of the project will increase the quality of learning in students with difficulty in critical reading.

For this reason, the development of the educational project is of great contribution to science, with the help of its guide would point to the reinforcement, recovery and activation of neuropsychological functions and brain gymnastics as a means of support to the sensory-motor aspect, taking into account that these functions are the basis of all learning.

At the international level, a study conducted in Sincelejo - Colombia by (Herrera Ucros \& Villalba Mercado) entitled "Critical reading processes, pedagogical medication to promote the development of critical thinking skills", is based on the need to effectively use all existing pedagogical tools to stimulate the need for students to read so that they can adapt to the educational environment in a satisfactory manner, developing intellectual, psychological and social skills and improving their performance in the classroom.

This study allowed to learn more about the different pedagogical strategies that can stimulate an efficient development of thinking skills, directly influencing academic improvement, applying the knowledge acquired in the classroom in different situations and problems that arise in daily life, thus increasing their interrelation with the environment. 
A study entitled "Critical reading strategies for academic improvement" conducted by (Benítez Villacís \& Gaibor Mestanza) in the city of Babahoyo, province of Los Ríos, promotes the application of different knowledge aimed at improving the reading comprehension of students, adapting to their educational needs by promoting active learning.

The aforementioned study suggests the need for teachers to be aware of the educational needs of students, in order to develop activities that promote greater performance of their intellectual skills, facilitating the understanding of content, as well as its implementation, improving the process of adaptation to the educational environment while generating new significant learning based on experiences.

"Critical reading and meaningful learning is inscribed in a concrete totality approach; that is to say, within a historical, social, ideological, political, economic, scientific, technological and cultural context in which it develops in permanent interrelation." (Gavilánez Gavilánez, 2013, p. 14).. From this perspective, the efficient use of critical reading allows to create a greater number of possibilities to create in the student different significant learning not only within the educational area, but also within all areas of knowledge, improving the adaptation with the environment, as well as making the right decisions, based on the cultural and social context in which an individual develops.

From another perspective, critical reading "Is a technique that allows discovering ideas and information within a written text." (Baquerizo Matute, 2013, p. 23).. Considering the above quote, critical reading is proposed as a strategy that allows greater concentration and understanding of what is read, stimulating the brain to analyze the information received by the individual, keeping the most relevant aspects of it so that they can be applied at the necessary time. 
Likewise, "It constitutes a skill that allows us in these times the understanding of the reality in which we are immersed". Gamboa Romero, M. A., Barros Morales, R. L., \& Barros Bastidas, C. (2016), (Baquerizo Matute, 2013, p. 23).. From this perspective, the author shows us how reading allows us to open new ways to knowledge, taking into account that reading leads us to the truth, an example of this is given in audio visual advertisements, in which everything is painted in the most practical and easy way, however, people do not realize the textual message shown in it, where the real values of the object are presented due to the disinterest in reading leaving aside the most essential aspects within communication.

On the other hand, "Reading must be influenced by the purpose for which we read and by the nature of the text itself." (Paúl \& Elder, 2014, p. 1).. Based on the above quote, a student should read with a previous purpose that is linked at the same time with a common interest, so that reading becomes interesting and concludes with the achievement of reaching different knowledge related to education in this case, for this the teacher should use tools that stimulate the need to expand the mental landscape guiding their students to self-educate in their free time.

When developing critical reading processes, it is important to establish different aspects that improve and delimit the essential purpose of reading, capturing the greatest number of data and information that serve as a basis for the understanding of educational content, increasing their performance inside and outside the classroom, expanding their capacity for reception, processing and analysis of the knowledge acquired.

The fact of reading productively should be focused on the area of knowledge that is intended to strengthen, for example, if you intend to read a historical novel in order to improve their knowledge in history, it would be important that at the same time read other books of real history taking into account that 
not everything embodied in a novel can be real, and the information would reach the reader wrongly.

When making a reference to meaningful learning in the school environment, this is oriented to how all the curricular contents presented to the students can give a logical meaning to the actions and experiences of daily life, keeping them permanently in the student's mind, waiting for the need to use them again at the right time.

The development of meaningful learning leads students to optimize their performance in the educational environment, since they can intertwine the curricular contents with the previous knowledge acquired in daily experiences, exploiting the teaching-learning process and systematizing the use of this knowledge in the resolution of situations that occasionally arise.

Significant learning is based on three essential developers, the first is the location of the resources, elements and didactic tools within the classroom, the second on the student's previous knowledge and finally the third is based on the motivation of the student in the acquisition of new significant learning. Currently, there are still teachers who do not give the respective importance to the efficient development of meaningful learning through the use of active and playful techniques, making classes tedious and boring, often forcing them to memorize the contents without taking into account that in doing so, the information is only stored for a moment and instantly discarded by the student's subconscious, leaving educational gaps.

It is essential that the teacher uses activities that help develop meaningful learning in the different areas of learning, so that the student's mind is exercised by processing knowledge in an interactive and reflective way, accelerating the assimilation of the same, as well as decision making depending on the relevance of the data in the student's mind. 


\section{MATERIALS AND METHODS}

The need to efficiently use different processes aimed at collecting truthful information from the very point where the problem arises, allowed the use of a methodology based on the qualitative paradigm in order to make a detailed description of the fact of study, facilitating the understanding of the aspects that caused it.

This research takes into account the importance of an efficient critical reading in the development of new significant learning, therefore, it uses different theoretical axes with the aim of promoting the study of a number of theories that support the issue raised, in order to generate viable proposals that can minimize or eliminate the problems encountered.

This study focuses on a field research that allowed to attend the place where the problem arises, also for the same the participation of the different strata belonging to the educational community was considered, analyzing in detail the perspective provided by each of them, checking the degree of knowledge about the influence of critical reading in the meaningful learning of students. The survey was used as a data collection tool, which was framed in a quantitative approach that facilitated the necessary analysis that could be shown in the different graphs and tables, respectively.

For the present work we have worked with a field research which allowed us to develop a systematic, strict and logical process of information selection, using different strategies that served as a basis for understanding the reality found without manipulating or controlling the variables, establishing itself as a reliable source of data.

Considering the theory of (Ibarra, 2011, p. 3). the exploratory research provides us with a more generalized vision of the problem established in the Educational Unit under study, analyzing different aspects that influenced the 
deficient critical reading of the students, thus optimizing the formulation of hypotheses and their verification within the context indicated above.

Documentary research served as a strategy to critically evaluate different documents that supported the research process, interpreting them in a methodical way to express the most representative ideas about the observed reality.

It is necessary to emphasize that this type of research promotes a systematized analysis of the different aspects related to critical reading and meaningful learning using documentation coupled to the existing needs, in an orderly and scientific manner, which served as a contribution to the construction of new knowledge.

The main strategies to be used in this project are aimed at carrying out training courses, workshops and conferences on an ongoing basis, as detailed below:

- Meeting with the leaders of the four communes

- Organization of seminars and workshops

- Project socialization

Field visits will be made to the San Vicente dam to attend meetings with the local inhabitants in order to plan the actions and strategies required by this project, especially with the leaders in the guidelines that obey a suitable methodology for this type of crop.

The studies and analyses to be carried out are: biological study of the microorganisms in the reservoir, analysis of the physical-chemical characteristics of the water body, bathymetry, georeferencing of possible cultivation sites.

\section{RESULTS}

The survey was carried out with the number of students obtained as a result of the non-probabilistic intentional sample, considering 50 students of the 7 th 
year of general basic education, as well as 5 teachers and 3 directors of the Benemérita Sociedad Filantrópica Educational Unit. The surveys were designed with 10 questions inherent to the importance of the subject and the proposal, in the model structured under the Likert scale.

Critical reading is indeed influential to a high degree which is demonstrated by the Chi-Square test which statistically demonstrates its influence on the quality of students' deficient development of meaningful learning.

Accordingly, it was observed that there are no didactic resources that can be coupled to the development of meaningful learning in the area of language and literature, considering that the existing ones are not adapted to the existing needs of students in the seventh year of general basic education. Therefore, the bibliographic and field research served as a basis to establish the problem and elaborate a viable proposal to improve the students' school performance.

Some teachers do not plan in advance the contents to be presented in class, which shows that they are not taking into account the learning problems that some students may present, leaving aside the application of techniques and strategies that promote meaningful learning.

The deficient development of new significant learning in students is a consequence of the lack of dynamic activities that can relate the experiences lived by the students with the contents presented in class, excluding the use of essential tools for their understanding.

\section{CONCLUSIONS}

The deficient critical reading existing in the students of the Benemérita Sociedad Filantrópica Educational Unit is caused by the lack of permanent training of the teachers, who do not motivate the students, causing them to 
get bored in class and therefore not understand the contents presented. For this reason, the teacher must find a way for the students to relate their experiences with the contents presented in class, indirectly stimulating the development of new significant learning.

In addition, many times, the strategies used are not directed to the existing problems, considering that everyone is a different world that needs activities that fit their requirements, so it is important to consider a bibliographic and field research to establish viable solutions in the short and long term, aimed at improving the critical reading of students, as well as their meaningful learning.

Class hours often become tedious and monotonous due to the little use of dynamic activities that encourage a more interactive critical reading, allowing an exchange of ideas about the subject to be treated. That is to say that the necessary didactic resources should be implemented in the classroom, so that the student can adapt within their educational environment, strengthening the development of new significant learning.

Finally, the teacher must establish a permanent communication with the representatives, encouraging the reinforcement at home of the contents learned in class, predisposing them to be interested in their educational development, motivating them to acquire new learning and therefore to improve their school performance, therefore the methodological strategies to be used must be directed to the existing problems.

\section{REFERENCES}

Baquerizo Matute, C. (2013). Application of critical reading in the teachinglearning processes for second year students majoring in language and literature. Guayaquil, Guayas, Ecuador: Universidad de Guayaquil. 
Gamboa Romero, M. A., Barros Morales, R. L., \& Barros Bastidas, C. (2016). La agresividad infantil, aprendizaje y autorregulación en escolares primarios. LUZ, 15(1), 105-114. Recuperado a partir de https://luz.uho.edu.cu/index.php/luz/article/view/743

Gavilánez Gavilánez, L. A. (2013). Critical reading and its incidence in the significant learning of students in the tenth years A and B of basic general education of the Colegio Nacional Experimental Ambato. Ambato, Tungurahua, Ecuador: Universidad Técnica de Ambato.

Ibarra, C. (October 26, 2011). Research methodology. Retrieved from http://metodologadelainvestigacinsiis.blogspot.com/2011/10/tiposde-investigacion-exploratoria.html

Mendoza, P. (2015). Anàliss y estrategias didàcticas y su influencia en el desempeño escolar . Guayaquil, Guayas, Ecuador: Norma.

Paul, R., \& Elder, L. (2014). Eduteka. Retrieved from Critical Reading: http://www.eduteka.org/pdfdir/LecturaCritica.pdf 